\title{
CHEMICAL COMPOSITION OF FRESHWATER CRAYFISH (PROCAMBARUS CLARKII) AND ITS NUTRITIVE VALUE
}

Mohamed H. Mona.; Naglaa S. Geasa.; Khadiga M. Sharshar and Emam M. Morsy.

Department of Zoology, Faculty of Science, Tanta University, Egypt.

(Received : November 7, 1999);

Key words: Crayfish, Procambarus clarkii, chemical composition, nutritive value.

\section{ABSTRACT}

The chemical composition of flesh and carapace of the freshwater
crayfish (Procambarus clarkii) was determined. The relationship between body weight, total length, yield of meat and carapace was established.Average chemical composition of the flesh of male was determined to be $7 \%$ moisture, $3.1 \%$ fat, $10.2 \%$ ash, $17.5 \%$ carbohydrate, $62.2 \%$ protein, calcium $2843 \mathrm{mg} / 100 \mathrm{~g}$, phosphorus $343.6 \mathrm{mg} / 100 \mathrm{~g}$; iron $11.7 \mathrm{mg} / 100 \mathrm{~g}$, zinc $15.1 \mathrm{mg} / 100 \mathrm{~g}$, Selenium $0.9 \mathrm{mg} / \mathrm{loog}$. The present study reveals that the higher protein content in muscle of males may be due to its faster growth rate than females. Moreover, it was indicated that the present investigated crayfish contains more phosphorus than fish and the carapace contains a higher values of iron, fat and carbohydrate than muscles.

Thus, it is safely to conclude that the flesh of $P$. clarkii is recommended to stand as a source of animal protein for Egyptian citizens and its carapace can be used as a forage for animals. 


\section{INTRODUCTION}

Recently, there is a growing awareness of the value of biochemical estimation of marine organisms for two purposes, the first is for understanding the process of its metabolism and physiological adaptations, while the second is for determining the possibility of using it as an alternative source of food.

Earlier investigations have shown the high nutritive and caloric value of shrimps as compared with other crustaceans and leanfish (Geng, 1925; Jones, 1926; Lanham \& Lemon, 1938; Schmidt, 1950; Varela, 1955; Dabrowski et al., 1969 and Bernice, 1972).

There are many investigations dealing with chemical composition of sea shellfish meat, an excellent review of which has been made by Börgstrom (1962). On the other hand, studies on chemical composition of meat of freshwater shellfish (Astacus leptodactylus) and (Astacus astacus) were conducted by Dabrowski et al. (1966).

The chemical composition of the crayfish Procambarus clarkii was investigated by many authors (Torreblance et al., 1991and 1992; Ishii et al., 1996 and 1998; Nagasawa et al., 1996; Foa \& Cooke, 1998; and Gradwell et al., 1998).

The present work deals with the chemical composition of muscles and carapace of the freshwater crayfish Procambarus clarkii which has lately invaded our waters and has become a substantial member of the aquatic fauna in Egypt particularly Nile Delta.

\section{MATERIAL AND METHODS}

Investigated specimens were collected using a $0.7 \mathrm{~cm}$ diagonal net size from El-Agezy drain at Tanta city, Gharbia Governorate Collected specimens were kept in fibre glass containers, $43 \times 23 \times 15.5 \mathrm{~cm}$ 
Chemical composition of freshwater crayfish (Procambarus clarkii) and its nutritive value

containing small pieces of rocks. Water was maintained at a depth of $12-$ $14 \mathrm{~cm}$. These containers were exposed to atmospheric air, natural light and at the room temperature, and specimens were fed with detritus, algae and some vegetation from the natural habitat. Investigated samples were catched by forceps then dried at room temperature for $12 \mathrm{hr}$ and then killed with chloroform vapor. The meat was secured from the tails and claws of the samples.

Morphometric analysis of the samples:

The crayfish were divided according to sex and the following measurements made: total length (the total length was considered as the distance from the rostrum to the end of the caudal plates), total weight, carapace weight and the meat yield of edible parts.

\section{Preparation of samples for chemical analysis:}

The carapace and meat yield of 20 male and 20 female samples were dried at $105^{\circ} \mathrm{C}$ to a constant weight.

Samples were crushed and finely ground in a porcelain mortar. Analyses were made on freshly ground meat samples immediately after preparation, without storing them at low temperature. Protein and fat were determined by the kjeldahl. All salts, Moisture, Ash and Carbohydrate were determined by atomic adsorption spectrophotometer.

\section{RESULTS}

Morphometric analysis:

Table (1) Shows that female crayfish $P$. clarkii of $8.5-11.5 \mathrm{~cm}$ in length and mean weight of 24.34 , yield from 16.7 to $23.49 \%$ of flesh (mean 20.5\%), while the male of the same length and mean weight of 29.41 , yielded from 17.2 to $23.7 \%$ of flesh (mean $21 \%$ ). It appears from figs $(1 \& 2)$ that there is a direct relationship between the total weight and 
carapace weight and meat yield weight. Bigger individuals generally have higher percentage of meat yield. The males are some what more efficient in meat than the females.

\section{Chemical analysis:-}

- Moisture.

- Moisture in both sexes of the investigated samples were nearly similar (Tables $2 \& 3$ ). The moisture of muscle and carapace in male are 7 and $6.2 \mathrm{~g} / 100 \mathrm{~g}$ and the moisture of muscle and carapace in the female are 5.6 and $5.5 \mathrm{~g} / 100 \mathrm{~g}$ respectively.

- Protein.

Proteins are more concentrated in the muscle of both sexes than in the carapace (Tables $2 \& 3$ ).

The muscle proteins of male is higher $(62.2 \mathrm{~g} / 100 \mathrm{~g})$ than the female $(58.6 \mathrm{~g} / 100 \mathrm{~g})$. On the contrary, the carapace protein of female is $23.5 \mathrm{~g} / 100 \mathrm{~g}$ and in the male is $15.6 \mathrm{~g} / 100 \mathrm{~g}$.

- Fat.

It is evident from the estimated values (Tables $2 \& 3$ ) that the fat level in both samples (muscle and carapace) of male crayfish is higher than that of female. The fat level in muscle of the male is $3.1 \mathrm{~g} / 100 \mathrm{~g}$ and $4.1 \mathrm{~g} / 100 \mathrm{~g}$ in the carapace. The fat content in muscle and carapace of the female is $1.7 \mathrm{~g} / 100 \mathrm{~g}$ and $1.8 \mathrm{~g} / 100 \mathrm{~g}$ respectively.

- Ash.

The total quantity of ash which gives an index of various inorganic elements in the body, does not show any marked difference in the values in the carapace of both sexes, while the ash in the muscle of male $(10.2 \mathrm{~g} / 100 \mathrm{~g})$ is higher than the female $(8.6 \mathrm{~g} / 100 \mathrm{~g})$. 
Chemical composition of freshwater crayfish (Procambarus clarkii) and its nutritive value

- Carbohydrate.

A perusal of Table 3 shows that carbohydrate in carapace is slightly less in the female $(64 \mathrm{~g} / 100 \mathrm{~g})$ than the male $(68.7 \mathrm{~g} / 100 \mathrm{~g})$. But, carbohydrate in the muscle is considerably higher in the female (25.5 $\mathrm{g} / 100 \mathrm{~g}$ ) of investigated sample than the male $(17.5 \mathrm{~g} / 100 \mathrm{~g}$ ) (Table 2).

\section{- Total energy.}

Calorific values of muscle in both sexs of crayfish (Table 2) are found to be higher in the female ( $352 \mathrm{kcal})$ than in the male $(347 \mathrm{kcal})$. The values of total energy for carapace are $366 \mathrm{kcal}$ for female and 374 kcal for male (Table 3).

\section{Minerals:}

- Calcium.

Calcium is considered the most important of the principal mineral element (macronutrients) which constitutes $60-80 \%$ of all the inorganic material in the body. It is obvious from Tables ( 4 \& 5) that the amount of calcium in muscle and carapace varies with sex. Large amount of calcium was found in the muscle of male $(2843 \mathrm{mg} / 100 \mathrm{~g})$ and the female has low value of calcium $(1474 \mathrm{mg} / 100 \mathrm{~g})$ in its muscle. Also, carapace of male and female of investigated sample contains 1766 and $1627 \mathrm{mg} / 100 \mathrm{~g}$ of calcium respectively.

\section{- Phosphorus.}

Obtained results demonstrate that the highest value of phosphorus is found in the muscle of both sexes. Table (4) indicates that the phosphorus values in muscle of male and female are 343.6 and 327.2 $\mathrm{mg} / 100 \mathrm{~g}$, while the level of phosphorus in carapace of male and female are 39.5 and $45 \mathrm{mg} / 100 \mathrm{~g}$ (Table 5) respectively. 


\section{- Iron, Zinc and Selenium.}

Tables $(4 \& 5)$ show that the value of iron is the highest and selenium is the lowest in muscle and carapace of both sex. Table (5) shows that the highest value of iron in carapace of female and male are $19.9 \mathrm{mg} / 100 \mathrm{~g}$ and $18.1 \mathrm{mg} / 100 \mathrm{~g}$ respectively, while the muscle contains low value of iron $(11.7 \mathrm{mg} / 100 \mathrm{~g}$ for male and $8.9 \mathrm{mg} / 100 \mathrm{~g}$ for fermale).

Conversely, the highest value of $\mathrm{Zn}$ was found in muscles of both sexes. The value of $\mathrm{Zn}$ in muscles of male and female are $15.1 \mathrm{mg} / 100 \mathrm{~g}$ and $9.5 \mathrm{mg} / 100 \mathrm{~g}$, while carapace of the male and female have low and nearly the same value of $\mathrm{Zn}(3.8 \mathrm{mg} / 100 \mathrm{~g})$.

The males of investigated sample have 0.9 and $1.2 \mathrm{mg} / 100 \mathrm{~g}$ of selenium in muscle and carapace respectively. While muscle and carapace of the female have $1.4 \mathrm{mg} / 100 \mathrm{~g}$ and $0.8 \mathrm{mg} / 100 \mathrm{~g}$ of selenium respectively

\section{DISCUSSION}

The present study reveals that muscle proteins of the crayfish have been observed to be more concentrated than carapace proteins. This may be due to the fact that proteins are the main components of contractile elements of striated muscles. This agrees with the previous finding of Sinha \& Ahmed (1978) who showed that muscle proteins were concentrated than hepatopancreatic proteins in crabs. In view of the fact that some males of decapod crustaceans grow faster than females (Orton, 1936) and show a greater oxygen consumption as well as a higher SDH activity (Ramamurthi, 1966) it may be concluded that the higher protein content in muscle of the male indicates a faster growth rate in males as compared to the females. 
Chemical composition of freshwater crayfish (Procambarus clarkii) and its nutritive value

The availability of such high protein in investigated species indicates their high nutritive value. This confirms the findings of Brige \& Juday (1922); Orr (1934a \& b) and Dabrowski et al. (1966).

The high values of phosphorus in muscle of crayfish Procambarus clarkii are in close agreement with values reported for American crayfish meat and shrimp flesh reported by Dabrowski et al. $(1966,1969)$. These values are higher than that found in the freshwater fishes such as tench and bream (Dabrowski et al., 1966).

The values of ash were similar with that reported in Streptocephalus dichotomus and Branchinella kugenumaensis shrimps by Bernice (1972) and higher than that reported in the crustacean Neomysis integer by Raymont et al. (1964).

The fairly high amount of fat and the moderate amount of carbohydrate present in muscle of the male probably indicate the demand of these materials for their various active metabalic processes for the rapid completion of their life cycle.

The obtained data indicate that carapace of the male contains moisture, fat, carbohydrate, selenium and calcium higher than female, but that of female contains high value of iron, phosphorus and protein. This indicates a slight difference in the values obtained for male and female, and the carapace contains a higher values of iron, fat and carbohydrates than the muscle.

In conclusion, the present work declares that the muscle of $P$. clarkii can stand as a source of animal protein for Egyptian people, many of them suffering from malnutrition, while the dried carapace can also act as a rich constituent of poultry food. This agrees with the previous findings of Huner \& Barr (1991) and Soliman, et al. (1998). 


\section{REFERENCES}

Bernice, R. (1972).Biochemical composition of Streptocephalus dichotomus Baird and Branchinella Kygenumaensis (Ishikawa). Hydrobiol., 39: 155-164.

Börgstrom, G. (1962). Shellfish protein-nutritive aspects, In fish as food, part 11. Academic press, Inc., New York and London, 115-147.

Brige, E.A. \& Juday, G. (1922). The inland lakes of Wisconsin. The plankton. I. Its quantity and chemical composition. Nat. Hist. Surv Bull. 64 Sci. ser. No. 13: 1-222.

Dabrowski, T.; Kolakowski, E.; Wawreszuk, H. \& Choroszucha. CZ. (1966). Studies on chemical composition of American Crayfish (Orconectes limosus) meat as related to its nutritive value. J. Fish. Res. Bd. Canada, 23:1653-1662.

Dabrowski, T, Kolakowski, E. \& Karnicka, B. (1969). Chemical composition of shrimp flesh (Parapenaeus spp) and its nutritive value. J. Fish. Res. Bd. Canada, 26: 2969-2974.

Foa, Lc. \& Cooke, IR. (1998). The ontogeny of GABA-and glutamatelike immunoreactivity in the embryonic Australian freshwater crayfish, Chernax destructor. Der. Brain Res., 107 (1): 33-42.

Geng, H. (1925). Der Fütterwërt der natürlichen fisch-Nahrung. Zeit. F. fischerei und deren Hilfswissenschaften, 23: 137-165.

Gradwell, M.J; Fan, T.W, \& Lanc A.N. (1998). Analysis of phosphorylated metabolites in crayfish extracts by twodimensional 1H-3IP NMR heteronuclear total correlation spectroscopy (hetero TOCSY), 263 (2): 139-149.

Huner, J.V. \& Barr, J.E. (1991). Red Swamp crawfish: Biology and Exploitation. $3^{\text {rd }}$ Ed. (E.B.C., ed.). Louisiana state univ., Baton Rouge, Louisiana. 
Chemical composition of freshwater crayfish (Procambarus clarkii) and its nutritive value

Ishii, K; Tsutsui, N; Watanabe, T; Yanagisawa, T. \& Nagasawa, H. (1998). Solubilization and chemical characterization of an insoluble matrix protein in the gastroliths of a crayfish, Procambarus clarkii. Biosci. Biotechnol. Biochem., 62(2): 291-296

Ishii, K; Yanagisawa, T. \& Nagasawa, H. (1996). Characterization of a matrix protein in the gastroliths of the crayfish Procombarus clarkii. Biosci. Biotechnol. Biochem., 60 (9): 1479-1482.

Jones, D. B. (1926). The nutritional value of oysters and other seafoods. Am. J. Public Health, 16: 1177-1182.

Lanham, W.B., \& Lemon, J.M. (1938). Nutritive value for growth of some proteins of fishery products. Food Res. 3: 549-553.

Nagasawa, H. Yang, WJ, shimizu, H. Aida, K. Tsutsumi, H.Terauchi, A \& Sonobe, H. (1996).Isolation and amino acid sequence of a molt-inhibiting hormone from the American crayfish, Procambarus clarkii. Biosci. Biotechnol. Biochem, 60(3): 554556.

Orr, A. P. (1934a). The weight and chemical composition of Euchaeta norvegica Boeck. Proc. Roy Sec. Edinb. B. 54: 51-55.

Orr, A. P. (1934b). On the biology of Calanus finmarchicus part IV. Seasonal changes in the weight and chemical composition in loch fyne. J. mar. biol. Ass. U. K.,19:631-632.

Orton, J. H. (1936). Experiments in sea on the rate of growth of some crustacean decapods. J. Mar. Biol. Ass. U. K., 20: 673-689.

Ramamurthi, R. (1966).Succinic dehydrogenasc activity in a freshwater crab. In relation to salinity stress. Comp. Biochem. Physiol.,19: 645-648. 
Raymont, J. E. G.; Austin, J. \& linford, E. (1964). Biochemical studies on marine Zooplankton. I. The biochemical composition of Neomysis integer. J. Cons. Int. Explor. Mer.,28: 354-363.

Schmidt, P. J. (1950).Analysis of freshwater fishes from canadian interior provinces. J. Fish. Res. Con. Pac. Fish. Exp. Stn. Industrial memo No. 13: 1-18.

Sinha, R. C. \& Ahmed, H. K. (1978). Some changes in biochemical composition with sex and size of the crab, Sesarma boulengeri Calman. Hydrobiologia, 61:15-19.

Soliman, G. N.; EL-Assal, F.; Salah EL-Deen, M. \& Hamdy, S.A. (1998). The reproductive biology of the red swamp crawfish Procambarus clarkii (Girard, 185) (Decapoda: Combaridae) in the River Nile, Egypt. Egypt. J. Zool., 30: 297-310.

Torreblanca, A; Del Ramo, J. \& Diaz-Mayans, J. (1991). Effect of cadmium on the biochemical composition of the freshwater crayfish Procambarus clarkii. Bull. Fnviron. Contam. Toxicol., 47 (6): 933-938.

Torreblanca, A; Del Ramo, J. \& Diaz-Mayans, J. (1992). Changes in biochemical composition of gills, hepatopancreas and muscle of the red crayfish Procambarus clarkii (Girard) after subiethal exposure to mercury. Comp. Biochem. Physiol.,102(2): 247252.

Varela, G. (1955). Sobre el valor biologico nutritivo de las proteinas del abadejo ahumado y del camaron. Anales Bromatol. Madrid, 7: 127-140. 
Chemical composition of freshwater crayfish (Procambarus clarkii) and its nutritive value

Table 1. Relationship between overall length of the carapace of crayfish $(P$. clarkii) and its weight, carapace and meat yield weights.

\begin{tabular}{|c|c|c|c|c|}
\hline \multirow{2}{*}{$\begin{array}{c}\text { Overall length } \\
\text { (cm) }\end{array}$} & \multirow{2}{*}{$\begin{array}{c}\text { Total weight } \\
\text { (g) }\end{array}$} & \multirow{2}{*}{$\begin{array}{c}\text { Carapace weight } \\
\text { (g) }\end{array}$} & \multicolumn{2}{|c|}{ Meat yield weight } \\
\hline & & & (g) & $(\%)$ \\
\hline \multicolumn{5}{|l|}{ Female } \\
\hline $8.5-8.9$ & 17.778 & 1.672 & 2.972 & 16.72 \\
\hline $9.0-9.4$ & 18.242 & 1.728 & 3.487 & 19.12 \\
\hline $9.5-9.9$ & 21.534 & 1.904 & 4.376 & 20.32 \\
\hline $10.0-10.4$ & 24.571 & 2.238 & 5.173 & 21.05 \\
\hline $10.5-10.9$ & 29.422 & 2.754 & 6.530 & 22.19 \\
\hline $11.0-11.4$ & 34.513 & 3.395 & 8.108 & 23.49 \\
\hline Mean & 24.34 & & & 20.48 \\
\hline \multicolumn{5}{|l|}{ Male } \\
\hline 8.5 - 8.9 & 18.497 & 1.742 & 3.182 & 17.20 \\
\hline $9.0-9.4$ & 24.731 & 2.063 & 4.896 & 19.80 \\
\hline $9.5-9.9$ & 25.343 & 2.472 & 5.253 & 20.73 \\
\hline $10.0-10.4$ & 28.400 & 2.928 & 6.246 & 21.99 \\
\hline $10.5-10.9$ & 35.272 & 3.950 & 7.944 & 22.52 \\
\hline $11.0-11.4$ & 44.263 & 4.688 & 10.488 & 23.69 \\
\hline Mean & 29.41 & & & 20.99 \\
\hline
\end{tabular}


Table 2. Chemical Composition of the meat yield and carapace of crayfish $(P$. clarkii) $\mathrm{g} / 100 \mathrm{~g}$.

\begin{tabular}{|l|c|c|c|c|}
\hline \multirow{2}{*}{ Chemical Composition } & \multicolumn{2}{|c|}{ Female } & \multicolumn{2}{c|}{ Male } \\
\cline { 2 - 5 } & Meat yield & Carapace & Meat yield & Carapace \\
\hline Moisture & 5.6 & 5.5 & 7 & 6.2 \\
\hline Protein & 58.6 & 23.5 & 62.6 & 15.6 \\
\hline Fat & 1.7 & 1.8 & 3.1 & 4.1 \\
\hline Ash & 8.6 & 5.2 & 10.2 & 5.4 \\
\hline Carbohydrate & 25.5 & 64 & 17.5 & 68.7 \\
\hline Kcal (energy) & 352 & 366 & 347 & 374 \\
\hline
\end{tabular}

Table 3. Chemical Composition of the carapace of crayfish ( $P$. clarkii) $\mathrm{g} / 100 \mathrm{~g}$.

\begin{tabular}{|l|c|c|}
\hline Chemical Composition & Female & Male \\
\hline Moisture & 5.5 & 6.2 \\
\hline Protein & 23.5 & 15.6 \\
\hline Fat & 1.8 & 4.1 \\
\hline Ash & 5.2 & 5.4 \\
\hline Carbohydrate & 64 & 68.7 \\
\hline Kcal (energy) & 366 & 374 \\
\hline
\end{tabular}




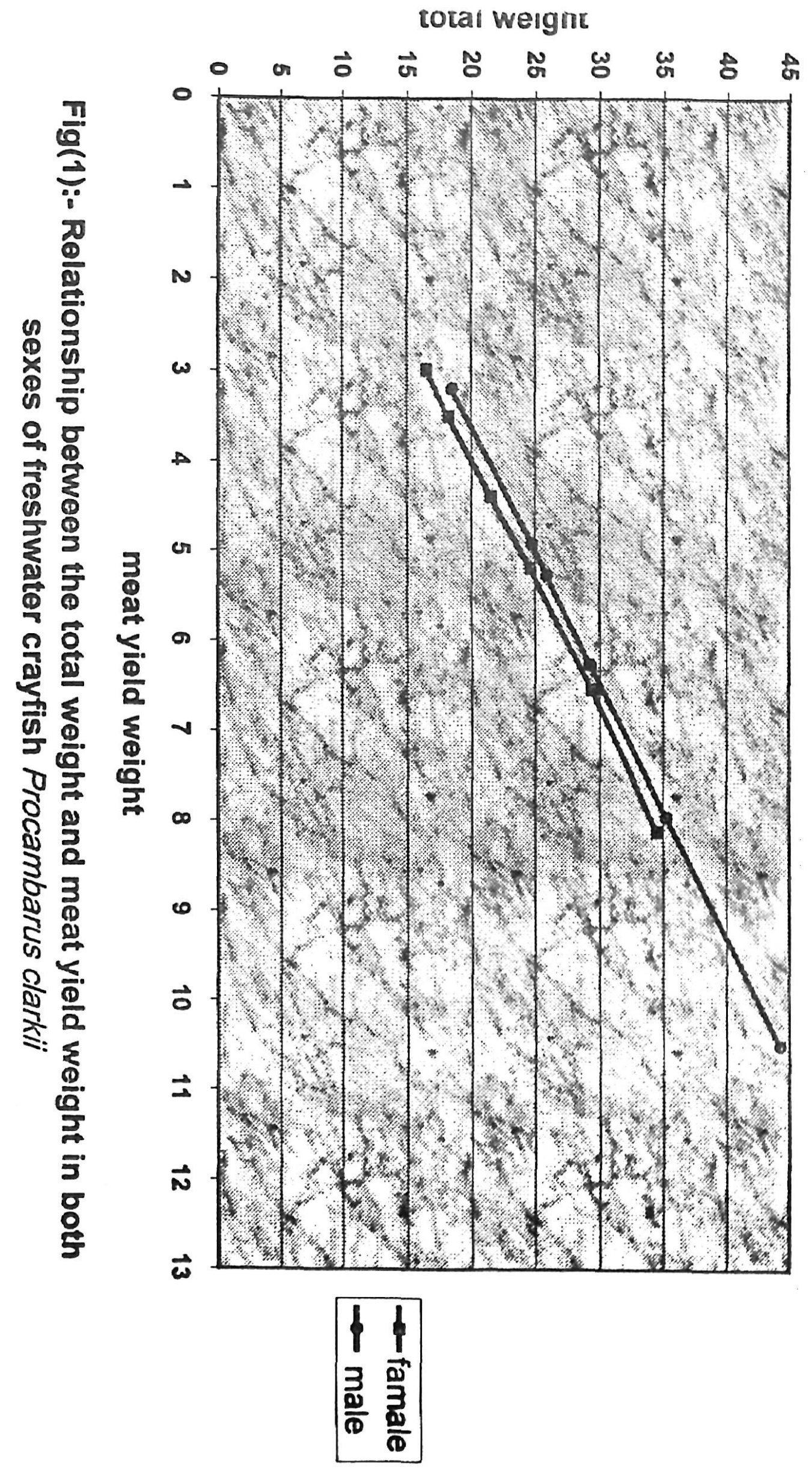




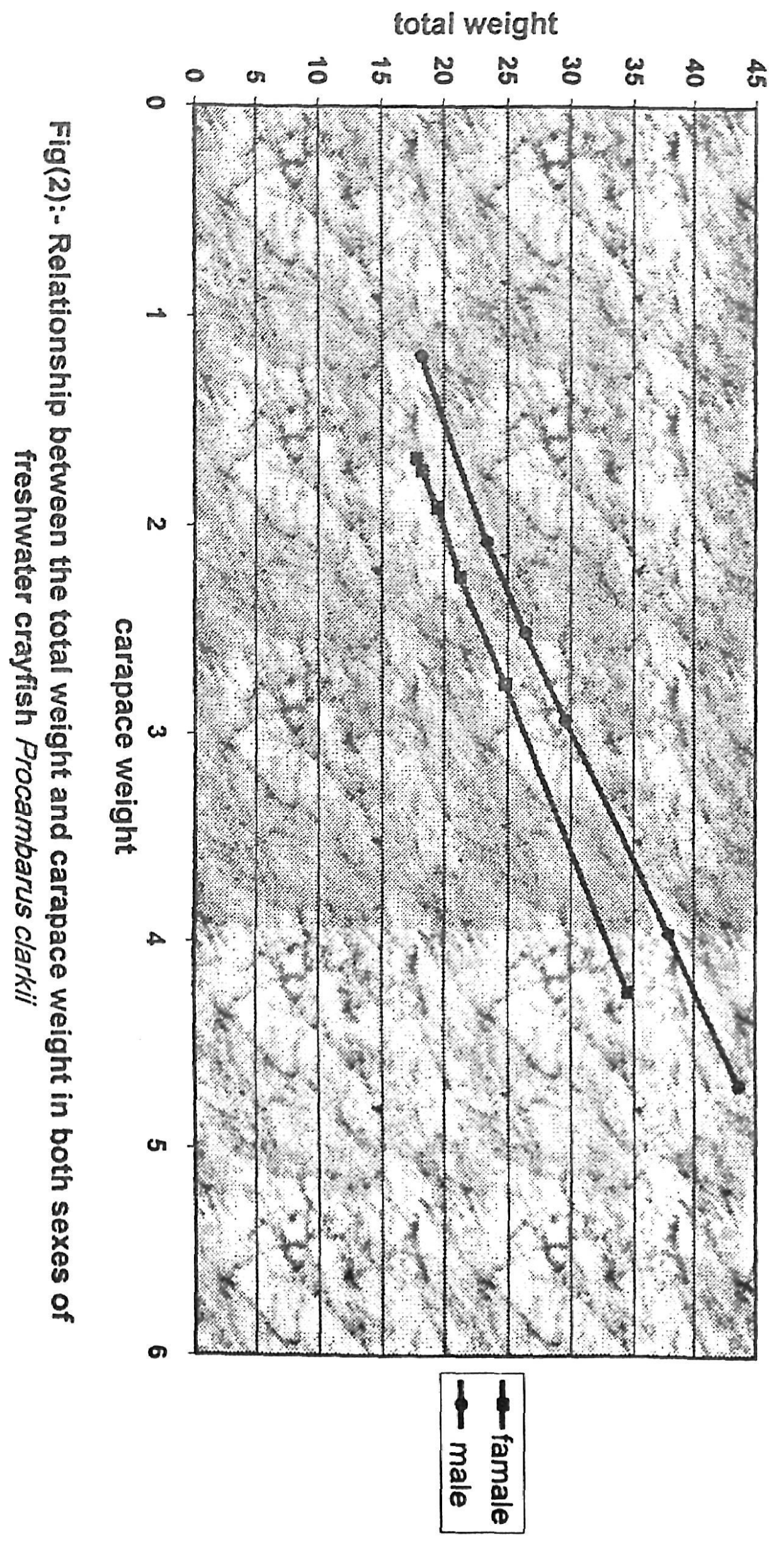

